\title{
PELUANG DAN TANTANGAN \\ LEMBAGA KEUANGAN SYARIAH INDONESIA PADA ERA PASAR BEBAS ASEAN
}

\author{
Abdul Hakim ${ }^{1}$ \\ e-mail : abakim087@gmail.com \\ UINSA SURABAYA
}

\begin{abstract}
Abstrak: Pada era Pasar bebas Asean merupakan salah satu tuntutan globalisasi yang tidak terelakkan, sehingga kita harus siap menghadapinya dengan persiapan-persiapan ekstra keras. Kita harus proaktif mengantisipasi kemungkinan dampak pasar bebas yang mungkin berdampak negatif terutama bagi pengembangan usaha rakyat kecil, tetapi kita masih memiliki peluang dimana masih luasnya pasar syariah yang belum digarap, dapat dilihat dari fakta bahwa ada lebih dari 200 juta Muslim di Indonesia dan terus meningkatnya muslim dunia yang senantiasa membutuhkan system keuangan syariah, hal ini merupakan peluang pasar yang lebar bagi industri keuangan syariah. Dan Lembaga perekonomian Islami merupakan salah satu instrument yang tepat untuk digunakan mengatur dan mengembangkan perekonomian, dan dismaping sebagai bagian dari sistem ekonomi, lembaga tersebut juga merupakan bagian dari keseluruhan sistem social yang ada.
\end{abstract}

Kata Kunci: Lembaga, Keuangan, Syari’ah

\section{A. PENDAhULUAN}

Lembaga perekonomian Islami merupakan salah satu instrument yang digunakan untuk mengatur dan mengembangkan ekonomi Islam. Sebagai bagian dari sistem ekonomi, lembaga tersebut merupakan bagian dari keseluruhan sistem sosial. Oleh karenanya, keberadaannya harus dipandang dalam konteks keseluruhan keberadaan masyarakat (manusia), beserta nilai-nilai yang melingkupinya. Islam menolak pandangan yang menyatakan bahwa ilmu ekonomi merupakan ilmu yang netral nilai. Padahal ilmu ekonomi merupakan ilmu yang sarat orientasi nilai.

Lembaga perekonomian Islam terus berupaya dalam berkontruibusi terhadap pertumbuhan dan pembangunan ekonomi, khususnya terhadap masyarakat industri modern. Produksi berskala besar dengan kebutuhan investasi yang membutuhkan modal besar tidak mungkin dipenuhi tanpa bantuan lembaga keuangan. Lembaga keuangan merupakan tumpuan bagi para pengusaha untuk mendapatakan tambahan modalanya melalui mekanisme kredit ataupun pembiayaan syariah, juga memperlancar transaksi ekonomi, sekaligus menjadi tumpuan investasi melalui mekanisme saving atau titipan.

\footnotetext{
${ }^{1}$ Dosen IAIN Sunan Ampel Surabaya
} 
Lembaga keuangan syariah telah memainkan peranan yang sangat besar dalam mendistribusikan sumber-sumber daya ekonomi di kalangan masyarakat, meskipun tidak sepenuhnya dapat mewakili kepentingan masyarakat yang luas.

Perkembangan industri keuangan syariah di dunia juga terlihat begitu pesat. System dan industri keuangan syariah tidak lagi menjadi isu local yang sifatnya terbatas ada di antara negara-negara muslim saja, tetapi juga telah menjadi trend global dimana negara-negara non-muslim sudah mengambil posisi dan inisiatif untuk mengadopsi serta mengembangkan sistem sekaligus industri keuangan syariah ini. Negara-negara yang memiliki industri keuangan terkemuka seperti Inggris, Prancis, Jepang, Hongkong dan Singapura terlihat berlomba-lomba untuk menjadikan negara mereka sebagai pusat keuangan syariah, baik di dunia maupun di kawasan regional. Bahkan lembaga-lembaga keuangan dunia seperti World Bank dan International Monetary Fund (IMF) telah pula menyatakan bahwa pengembangan keuangan syariah telah menjadi salah satu program utama mereka ${ }^{2}$

Kondisi ini setidaknya disebabkan oleh dua factor: Pertama, semakin banyaknya Negara baik muslim maupun non-muslim yang mengembangkan industri keuangan syariah dan perkembangan industri tersebut menunjukkan angka pertumbuhan yang sangat tinggi, sehingga diperkirakan dalam waktu yang tidak lama industri ini akan memainkan peran yang signifikan dalam percaturan industri keuangan dunia. Kedua, krisis keuangan yang menghantam banyak negara, tidak hanya negara-negara emerging market (1998 - 2005) tetapi juga negara-negara maju (2008 - 2011), dalam kurun waktu dua dekade terakhir ini mendorong banyak pihak untuk mencari alternative system keuangan yang lebih kuat. Alternative system keuangan tersebut diharapkan bukan hanya tahan dari guncangan krisis tetapi juga mampu mencegah krisis itu terjadi.

Sementara itu sekitar dua dasawarsa belakangan ini, kecenderungan untuk mewujudkan pasar bebas (free market) juga semakin kuat. Kecenderungan itu akan diwujudkan pada tingkat internasional dan tingkat regional. Di peringkat internasional terlihat pada persetujuan GATT (General Agreement on Tariff and Trade), serta terbentuknya WTO (World Trade Organization). Di peringkat regional bisa dilihat dari makin menguatnya kerjasama ekonomi dalam kawasan tertentu seperti Uni Eropa, AFTA, NAFTA, APEC dan terakhir CAFTA. CAFTA kini sudah diterapkan dengan segala dampak positif dan negatifnya. Sedangkan di wilayah Asia Tenggara sendiri dicanangkan AFTA (ASEAN Free Trade Area) dam ASEAN Economi Community (AEC).

Era pasar bebas di antaranya ditandai dengan adanya fenomena penting dalam bidang ekonomi. Kegiatan ekonomi dunia tidak hanya dibatasi oleh faktor batas geografi, bahasa, budaya dan ideologi, akan tetapi lebih karena faktor saling membutuhkan dan saling bergantung satu sama lain. Dunia menjadi seakan-akan tidak ada batas, terutama karena perkembangan teknologi informasi yang begitu pesat.

\footnotetext{
${ }^{2}$ Muhamad, Lembaga Keuangan Umat Kontemporer, UII Press Yogyakarta, 2000, hal 25
} 
Keadaan yang demikian melahirkan banyak peluang sekaligus tantangan, terutamanya dalam upaya pengembangan ekonomi Islam. ${ }^{3}$

Tujuan pasar bebas secara selintas memang positif, yakni agar perekonomian suatu negara bisa lebih maju dan berkembang. Berbagai studi memperlihatkan bahwa perdagangan dunia akan meningkat dengan berlakunya sistem pasar bebas. Peningkatan volume perdagangan berarti peningkatan produksi, yang berarti pula peningkatan lapangan kerja dan pada akhirnya peningkatan pendapatarn dan kesejateraan. Namun dalam praktek dan perkembangannya pasar bebas juga dapat menimbulkan ekses nehgatif dan masalah baru.

Dalam menghadapi era pasar bebas tersebut, tentunya lembaga-lembaga keuangan syariah akan menghadapi tantangan-tantangan baru di samping memiliki peluangpeluang. Oleh karenanya perlu difikirkan dan disiapkan langkah-langkah antisipasi dalam menghadapi kondisi tersebut. Termasuk akan ada kecenderungan dalam perkembangan ekonomi pada era global tersebut untuk lebih memperhatikan etika dalam aktivitas ekonomi.

Dalam tulisan ini, akan diungkap lebih lanjut tentang kecenderungan dan perkembangan ekonomi era globalisasi sekaligus mengungkapkan peluang dan tantangan pengembangan lembaga keuangan syariah dalam konteks trend perkembangan ekonomi era global tersebut. Secara khusus tulisan ini mengupas tentang bagaimana peluang-peluang dan tantangan-tantangan yang dihadapi oleh lembagalembaga keuangan syariah Indonesia pada era pasar bebas ASEAN 2015 agar dapat terus eksis dan bahkan mengalami kemajuan.

\section{B. LEMBAGA KEUANGAN SYARIAH}

\section{Pengertian}

Lembaga keuangan adalah semua badan yang kegiatannya bidang keuangan, melakukan penghimpunan, dan penyaluran dana kepada masyarakat, terutama guna membiayai investasi perusahaan (SK Menkeu RI No 792/90). Sering juga disebut sebagai suatu lembaga yang melancarkan pertukaran barang dan jasa dengan penggunaan uang atau kredit dan membantu menyalurkan tabungan sebagian masyarakat kepada masyarakat yang membutuhkan pembiayaan dana untuk investasi

Sedang Lembaga Keuangan Islam atau yang lebih popular disebut Lembaga Keuangan Syari'ah adalah suatu lembaga keuangan yang prinsip operasinya berdasarkan pada prinsip-prinsip syari'ah Islamiah. Dalam operasionalnya lembaga keuangan Islam ini harus menghindari unsur riba, gharar, maisir dan akad-akad yang bathil. ${ }^{4}$

Tujuan utama pendirian lembaga keuangan Islam adalah untuk menunaikan perintah Allah dalam bidang ekonomi dan muamalah serta membebaskan masyarakat Islam dari kegiatan-kegiatan yang dilarang oleh agama Islam. Untuk melaksanakan

\footnotetext{
${ }^{3}$ Muhamad, Prinsip-prinsip Akuntansi dalam Al-Quran, UII Press Yogyakarta, 2000, hal 5

4 Andri Soemitro, Bank \& Lembaga Keuangan Syariah, KPM Group, Jakarta 2009.h. 27
} 
tugas mulia ini sekaligus untuk menyelesaikan masalah yang memerangkap umat Islam, bukanlah hanya menjadi tugas seseorang atau sebuah lembaga, tetapi merupakan tugas dan kewajiban setiap muslim. ${ }^{5}$

\section{Bentuk-bentuk Lembaga Keuangan Syariah Di Indonesia}

1. Perbankan Syariah

Adalah bank yang menjalankan kegiatan usahanya berdasarkan prinsip syariah. Menurut jenisnya bank syariah dibedakan menjadi Bank Umum Syariah (BUS), Unit Usaha Syariah (UUS), dan Bank Pembiayaan Rakyat Syariah (BPRS). Saat ini keberadaan Bank Syariah diatur dalam UU. No. 21 tahun 2008 tentang Bank Syariah.

Bank Syariah melakukan bentuk kegiatan usaha yang hampir sama dengan bank konvensional, yaitu melakukan penghimpunan dana dari masyarakat dan penyaluran dana pada masyarakat. Bank syariah juga menyediakan jasa keuangan lainnya. Perbedaannya adalah bahwa semua kegiatan tersbut dilakukan oleh bank syariah dengan berdasarkan pada prinsip syariah. Implikasinya bank syariah memiliki berbagai variasi akad sebagaimana yang lazim dalam fiqh muamalat. ${ }^{6}$

2. Baitul Mal Wat Tamwil (BMT)

Baitul Maal wat Tamwil (BMT) atau Balai Usaha Mandiri Terpadu, adalah lembaga keuangan mikro yang dioperasikan dengan prinsip bagi hasil, menumbuh kembangkan derajat dan martabat serta membela kepentingan kaum fakir miskin, ditumbuhkan atas prakarsa dan modal awal dari tokoh-tokoh masyarakat setempat dengan berlandaskan pada system ekonomi yang salam.

Keberadaan BMT dapat dipandang memiliki dua fungsi utama, yaitu sebagai media penyalur pendayagunaan harta ibadah, serta bergerak di bidang investasi yang berifat produktif sebagaimana layaknya bank.

BMT bersifat informal karena lembaga ini didirikan oleh Kelompok Swadaya Masyarakat (KSM) yang berbeda dengan lembaga perbankan dan lembaga keuangan lainnya. ${ }^{7}$

3. Asuransi Syariah

Asuransi Syariah adalah asuransi yang dijalankan berdasarkan prinsip takaful, yaitu suatu skema kerjasama yang dilandasi oleh nilai-nilai ukhuwah, solidaritas, saling menjamin untuk memberikan bantuan finansial kepada peserta takaful jika membutuhkannya dan mereka sepakat untuk memberikan konstribusi untuk tercapainya tujuan tersebut.

Menurut Fatwa DSN MUI N0, 21 tahun 2001 tentang Asuransi Syariah, dijelaskan bahwa Asuransi Syariah adalah usaha saling melindungi dan tolong menolong di antara sejumlah orang/pihak melalui investasi dalam bentuk asset

\footnotetext{
${ }^{5}$ Veithzal Rival. Islamic financial Management. Jakarta: Galia Indonesia 2010.

${ }^{6}$ Andri Soemitro,.h. 61

${ }^{7}$ http://anshorudin.blogspot.com/2012/03/lembaga-ekonomi-islam.html.Dikutip tgl. 19 Desember 2013
} 
dan atau tabarru' yang memberikan pola pengembalian untuk menghadapi resiko tertentu melalui akad yang sesuai dengan syariah. ${ }^{8}$

4. Reksadana Syariah

Menurut pengertian hukum di Indonesia reksa dana adalah wadah yang dipergunakan untuk menghimpun dana dari masyarakat pemodal untuk selanjutnya di investasikan dalam portofolio efek oleh manajer investasi.

Penyerahan dana yang dilakukan oleh investor memerlukan jaminan bahwa pengelola dana tidak melakukan tindakan tidak terpuji. Oleh karena itu diperlukan suatu lembaga yang menjadi penjaga harta yang berbentuk efek. Lembaga itu disebut custodian yang merupakan sebuah bank, karenanya disebut bank custodian.

Sedangkan Reksa Dana Syariah merupakan sarana investasi campuran yang menggabungkan saham dan obligasi syariah dalam satu produk yang dikelola oleh manajer investasi. Manajer investasi menawarkan Reksa Dana Syariah kepada para investor yang berminat, sementara dana yang diperoleh dari investor tersebut dikelola oleh manajer investasi untuk ditanamkan dalam saham atau obligasi syariah yang dinilai menguntungkan.

Payung hukum Rekasadana Syariah adalah UU No. 8 tahun 1995 Tentang Pasar Modal dan Fatwa DSN MUI No. 20/DSN/MUI/IX/2000. Tentang Pedoman Pelaksanaan Investasi Untuk Reksadana Syariah. ${ }^{9}$

5. Pegadaian Syariah

Menutut KUH Perdata Pasal 1150 disebutkan, Gadai adalah suatu hak yang diperoleh seorang yang berpiutang atas suatu barang bergerak, yang diserahkan kepadanya oleh seorang berutang atau oleh seorang lain atas namanya, dan yang memberikan kekuasaan kepada kepada orang yang berpiutang itu untuk mengambil pelunasan dari barang tersebut secara didahulukan daripada orang yang berpiutang lainnya, dengan pengecualian biaya untuk melelang barang tersebut dan biaya yang telah dikeluarkan untuk menyelamatkannya setelah barang itu digadaikan, biaya-biaya mana harus didahulukan.

Gadai Syariah (Rahn) adalah menahan salah satu bentuk harta milik nasabah atau Rahin sebagai barang jaminan atau marhun atas hutang/pinjaman atau marhun bih yang diterimanya. Marhun tersebut memiliki nilai ekonomis sehingga pihak yang menahan memperoleh jaminan untuk mengambil kembali seluruh atau sebagian piutangnya. ${ }^{10}$

Pegadaian Syariah menjalankan operasinya berdasarkan prinsip syariah. Payung hukum Pegadaian Syariah di Indonesia adalah Fatwa DSN MUI No.25 tahun 2002. tentang Rahn, yang menyatakan bahwa pinjaman dengan menggadaikan barang sebagai jaminan utang dalam bentuk rahn diperbolehkan.

6. Pasar Modal Syariah

Istilah sekuritas (securities) seringkali disebut juga dengan efek, yakni sebuah nama kolektif untuk macam-macam surat berharga, misalnya saham,

${ }^{8}$ Wirdyaningsih, Bank Dan Asuransi Islam Di Indonesia, Kencana Prenanda Media, Jakarta, 2005, h.179.

${ }_{9}^{9}$ Abdul Ghafur Anshori, Aspek Hukuk Reksadana Syariah Di Indonesia, Refika Aditama, Bandung, 2008, h. 71.

${ }^{10}$ Sasli Rais, Pegadaian Syariah: Konsep dan Sistem Operasional (Suatu Kajian Kontemporer, UI Press, Jakarta, 2005. h. 38. 
obilgasi, surat hipotik, dan jenis surat lain yang membuktikan hak milik atas sesuatu barang. Dengan istilah yang hampir sama, sekuritas juga dapat dipahami sebagai promissory notes/commercial bank notes yang menjadi bukti bahwa satu pihak mempunyai tagihan pada pihak lain.

Adapun,yang dimaksud dengan sekuritas syariah atau efek syariah adalah efek sebagaimana dimaksud dalam peraturan perundang-undangan di bidang pasar modal yang akad, pengelolaan perusahaan, maupun cara penerbitannya memenuhi prinsip-prinsip syariah.

Dengan demikian Pasar modal syariah adalah pasar modal yang seluruh mekanisme kegiatannya terutama mengenai emiten, jenis efek yang diperdagangkan, serta mekanisme perdagangannya sendiri telah sesuai dengan prinsip-prinsip syariah.

7. Pasar Uang Syariah

Merupakan mekanisme yang memungkinkan lembaga keuangan syariah untuk menggunakan instrument pasar dengan mekanisme yang sesuai dengan prinsip-prinsip syariah baik untuk mengatasi persoalan kekurangan likuiditas maupun kelebihan likuiditas.

Kebijakan mengenai Pasar Uang Syariah di Indonesia didasarkan pada Peraturan Bank Indonesia No.10/36/PBI/2008 tentang Operasi Moneter Syariah yang merupakan pengejawantahan pengendalian moneter berdasarkan prinsip syariah dalam rangka mendukung tugas Bank Indonesia dalam menetapkan dan melaksanakan kebijakan moneter. ${ }^{11}$

8. Dana Pensiun Syariah

Menurut UU No. 11 tahun 1992 tentang Dana Pensiun, dijelaskan bahwa Dana Pensiun adalah badan usaha yang menjalankan program untuk memberikan manfaat pensiun. Sedang Dana Pensiun Syariah adalah dana pensiun yang dikelola berdasarkan prinsip syariah.

Dana Pensiun Syariah Untuk memperoleh uang pensiun setelah purna tugas merupakan harapan yang ideal bagi setiap pekerja. Apalagi setelah sekian tahun mencurahkan tenaga, waktu dan pikirannya bagi perkembangan dan kemajuan perusahaan tempatnya bekerja, dan wajar kiranya saat usianya sudah lanjut dan tidak produktif lagi perusahaannya masih mengingat jasanya dalam bentuk pemberian pensiun. Namun tidak semua perusahaan menyediakan pensiun dan hanya sedikit sekali perusahaan memberikannya.

9. Leasing Syariah

Perusahaan Sewa guna usaha lebih ditekankan kepada pembiayaan terhadap barang-barang modal tahan lama atau jangka panjang yang diinginkan oleh nasabahnya dengan system syariah, dalam hal ini bersendikan konsep ijarah.

10. Modal Ventura Syariah

Bila mau berkaca, maka ada pelajaran penting yang dapat diambil dari pengalaman venture capital. Venture capital pada hakekatnya tidak berbeda

\footnotetext{
${ }^{11}$ Andri Soemitro, h.203.
} 
secara substantif dibandingkan dengan musyarakah. Pengalaman di banyak tempat dan banyak negara, termasuk negara maju, membuktikan betapa besar dan pentingnya peran yang disumbangkan oleh jenis usaha venture capital ini pada pengembangan usaha dengan basis yang lebih adil, dibandingkan praktik perbankan konvensional.

Sudah umum diketahui, betapa sejumlah perusahaan kaliber dunia seperti Microsoft dan Macintosh computer memulai usahanya dengan bekerjasama modal bersama perusahaan Venture Capital. Di dunia barat pada umumnya, cukup tinggi pengakuan akan peran dan kontribusi jenis perusahaan Venture Capital sebagai mitra usaha dalam permodalan. Terbukti kemudian bahwa usaha yang dibantu seperti Microsoft dan Macintosh melejit menjadi perusahaan raksasa kaliber dunia, dan usaha-usaha jenis Venture Capital tetap bisa survive dalam posisi mereka sebagai perusahaan mitra modal.

Seperti diungkapkan di muka, bahwa pada hakekatnya tidak ada perbedaan substansi antara praktik venture capital dan musyarakah. Oleh karena itu, mestinya perlu menjadi pertanyaan dan pelajaran bagi dunia perbankan syariah, mengapa hal ini tidak dijadikan insipirasi, sehingga salah satu kelemahan perbankan syariah dalam "potofolio produk" dan sekaligus rendahnya peran bank syariah dalam mendorong pertumbuhan sektor riel dapat diatasi. Di sisi lain, memperbesar porsi musyarakah dapat pula memberikan potensi keuntungan yang jauh lebih besar bagi bank syariah. ${ }^{12}$

11. Anjak Piutang Syariah

Perusahaan Anjak Piutang, perusahaan yang usahanya adalah mengambil alih pembayaran kredit suatu perusahaan, terutama dengan cara mengambil kredit bermasalah dengan mekanisme syariah. Dalam hal ini Anjak Piutang Syariah dijalankan dengan berdasar pada prinsip akad hiwalah dalam fiqh muamalat.

12. Koperasi Syariah

Saat ini beroperasinya koerasi syariah lebih banyak mengambil bentuk Koperasi Jasa Keuangan Syariah (KJKS). Sistem ini memperbaiki sistem Simpan Pinjam konvensional yang berusaha menghimpun dana dari anggotanya kemudian menyalurkan kembali kepada para anggota koperasi dan masyarakat. Simpan pinjam konvensional dijalankan dengan penerapan bunga.

\section{Lembaga ZISWA}

Lembaga Zakat, Infak, Shadaqah dan Waqaf. Lembaga ini merupakan lembaga yang hanya ada dalam system keuangan Islam, karena Islam mendorong umatnya untuk menjadi sukarelawan dalam beramal (volunteer). Dana ini hanya bisa dialokasikan untuk kepentingan social atau peruntukan yang telah digariskan menurut syariah Islam.

Secara khusus pengelolaan zakat adalah kegiatan perencanaan, pengorganisasian, pelaksanaan, serta pendayagunaan zakat. ${ }^{13}$

\footnotetext{
${ }^{12}$ Soemitro, h. 307

${ }^{13}$ Ibid. h. 408
} 


\section{Mekanisme Operasional Lembaga Keuangan Syariah}

Secara umum mekanisme operasional dari lembaga-lembaga keuangan syariah tersebut adalah menerapkan prinsip-prinsip akad dalam fiqih muamalat yang pada intinya adalah menghindari unsure riba, maisir, gharar, dan akad yang bathil. Prinsipprinsip akad yang biasanya diterapkan adalah:

1. Musyarakah

Adalah akad kerjasama antara dua pihak atau lebih untuk suatu usaha tertentu, dimana masing-masing pihak memberikan kontribusi dana dengan ketentuan bahwa keuntungan dibagi berdasarkan kesepakatan sedangkan risiko berdasarkan porsi kontribusi dana. ${ }^{14}$

2. Mudharabah

Mudharabah adalah akad kerjasama usaha antara dua pihak dimana pihak pertama (pemilik dana) menyediakan seluruh dana, sedangkan pihak kedua (pengelola dana) bertindak selaku pengelola, dan keuntungan usaha dibagi di antara mereka sesuai kesepakatan sedangkan kerugian finansial hanya ditanggung oleh pengelola dana. Prinsip akad mudharabah banyak dalam perbankan syariah. ${ }^{15}$

3. Ijarah

Adalah akad pemindahan hak guna (manfaat) suatu barang atau jasa dalam waktu tertentu dengan adanya pembayaran upah (ujrah), tanpa diikuti dengan pemindahan kepemilikan atas barang tersebut.

Kegiatan ijarah ini dalam perbankan syariah dijalankan dengan menyewakan simpanan (safe deposit box) dan jasa tata-laksana administrasi dokumen (custodian), dalam hal ini bank mendapatkan imbalan sewa dari jasa tersebut. Leasing (Sewa Guna Usaha) menerapkan akad ijarah ini.

4. Wadiah

Penerapan prinsip wadiah yang dilakukan adalah wadiah yad dhamanah yang diterapkan pada rekaning produk giro. Berbeda dengan wadiah amanah, dimana pihak yang dititipi (bank) bertanggung jawab atas keutuhan harta titipan sehingga ia boleh memanfaatkan harta titipan tersebut. Sedangkan pada wadiah amanah harta titipan tidak boleh dimanfaatkan oleh yang dititipi. Akad wadiah banyak diterapkan dalam perbankan syariah.

5. Rahn

Adalah penyerahan barang yang dilakukan oleh muqtaridh (orang yang berhutang) sebagai jaminan atas hutang yang diterimanya. Dengan demikian pihak yang member hutang memperoleh jaminan untuk mengaambil kembali seluruh atau sebagian piutangnya apabila peminjam tidak mampu membayar hutangnya. Prinsip akad ini diterapkan dalam Pegadaian Syariah.

6. Hiwalah

Adalah akad pengalihan tanggungan hutang dari pihak pertama kepada pihak kedua yang memiliki hutang pada pihak pertama. Akad ini menjadi dasar Lembaga Anjak Piutang Syariah,

7. Wakalah

\footnotetext{
${ }^{14}$ Muhammad Syafi'I Antonio, Bank Syariah Dari Teori Ke Praktek,(Gema Insani: Jakarta) 2001, 90.

15 Ibid. h. 95.
} 
Yaitu akad pemberian kuasa dari seorang muwakkil (Yang mewakilkan) kepada penerima kuasa (wakil) atas nama muwakkil (pemberi kuasa). Prinsip akad ini hampir digunakan atau diperlukan dalam operasional semua jenis lembaga keuangan syariah.

8. Kafalah

Kafalah merupakan jasa jaminan, yaitu kesanggupan untuk memenuhi hak yang telah menjadi kewajiban orang lain. Atau kesanggupan untuk mendatangkan barang yang ditanggung atau untuk menghadirkan orang yang mempunyai kewajiban terhadap orang lain. Prinsip akad ini utamanya menjadi landasan dalam operasioanl lembaga Asuransi Syariah

9. Bai'.

Merupakan akad jual beli, yaitu tukar menukar harta dengan harta lain melalui cara-cara yang ditentukan oleh syara'. Akad bai' dapat digunakan sebagai sarana untuk memiliki barang atau manfaat dari suatu barang untuk selama-lamanya. Akad bai' memiliki beberapa bentuk di antaranya :

- Murabahah, yaitu akad jual beli barang dengan menyatakan harga dan keuntugan yang disepakati antara penjual dan pembeli.

- Salam, yaitu penjualan suatu barang dengan menggunakan lafadz salam atau salaf, meyebut sifat-sifatnya sebagai persyaratan jual beli, sedangkan barangnya masih dalam tanggungan penjual.

- Istisna', yaitu akad jual beli dengan ketentuan bahwa penjual ditugaskan untuk membuat suatu barang oleh pemesan, dengan bahan baku atau modal pembuatan dari produsen (penjual) dengan mengikuti cara-cara tertentu.

10. Qardh

Yaitu memberikan atau menghutangkan harta kepada orang lain tanpa mengharapkan imbalan, untuk dikembalikan kepada pemberi pinjaman dengan pengganti yang sama dan dapat ditagih atau diminta kembali kapan saja penghutang menghendaki. Akad ini diperbolehkan bahkan dianjurkan dengan tujuan menolong atau meringankan beban orang lain. ${ }^{16}$

\section{Perkembangan Lembaga Keuangan Syariah Indonesia}

Perkembangan industry keuangan syariah dinilai cukup menggembirakan. Hal ini antara lain dapat dilihat dari berbagai pertumbuhan yang dicapainya. Kepala Eksekutif Industri Keuangan Non Bank (IKNB) OJK Firdaus Jaelani mengungkapkan bahwa sampai tahun 2007 total asset lembaga keuangan syariah baru mencapai 38 trilyun, sedangkan pada tahun 2012 sudah mencapai 247 trilyun. Porsi keuangan syariah meningkat dari 4,9 persen menjadi 19,2 persen tahun 2012, Pada mulanya hanya didominasi oleh perbankan syariah tapi sekarang lembaga yang lain juga cukup berkembang, terutama Asuransi Syariah, lembaga pembiayaan syariah, lembaga penjaminan syariah, pegadaian syariah dan peruasahaan modal ventura syariah.

${ }^{16}$ Dumairi Nor Dkk. Ekonomi Syariah Versi Salaf,(Pustaka Sidogiri: Pasuruan), 2008. h.100 
Mempertegas hal tersebut ketua MUI KH. Ma'ruf Amin juga menyatakan bahwa pertumbuhan lembaga keuangan syariah yang mencapai $34 \%$ telah melebihi pertumbuhan lembaga keuangan konvensional yang hanya $15-20 \%$ saja. ${ }^{17}$

Dasar pemikiran dikembangkannya lembaga keuangan Islam di Indonesia adalah untuk memberikan pelayanan kepada sebagian masyarakat IndonesiaIndonesia, karena bank-bank tersebut menjalankan sistem bunga. Sebagian masyarakat Indonesia yang mayoritas muslim, meyakini bahwa aktivitas lembaga keuangan yang menjalankan praktek bunga tidak sesuai dengan prinsip Syari'ah Islamiyah, sehingga keikutsertaan mereka dalam sektor keuangan tidak optimal. Dengan dikembangkannya lembaga keuangan yang dijalankan dengan prinsip-prinsip Syari'ah diharapkan seluruh potensi ekonomi masyarakat Indonesia yang belum dioptimalkan dapat dioptimalkan.

Adapun secara khusus yang menjadi leading sector sekaligus perintis Lembaga Keuangan Syariah di Indonesia adalah perbankan syariah. Perkembangan mutakhir perbankan syariah di Indonesia dapat dilihat pada tabel di bawah ini. ${ }^{18}$

\section{Perkembangan Lembaga Keuangan (Perbankan) Syariah Di Indonesia}

\begin{tabular}{|l|l|l|l|l|l|l|l|}
\hline \multirow{2}{*}{ No } & \multirow{2}{*}{ Aspek } & \multicolumn{6}{|c|}{ Tahun } \\
\cline { 3 - 8 } & & 2007 & 2008 & 2009 & 2010 & 2011 & 2012 \\
\hline 1 & Jumlah Bank & 29 & 32 & 31 & 34 & 34 & 35 \\
\hline 2 & Jumlah Kantor & 568 & 790 & 998 & 1.477 & 1.702 & 2.227 \\
\hline 3 & $\begin{array}{l}\text { Penyaluran Dana } \\
\text { (Milliar) }\end{array}$ & 32.304 & 48.264 & 64.355 & 94.884 & 140.980 & 188.562 \\
\hline 4 & Aset Perbankan & & & & & & \\
& Syariah (Milyar) & & & & & & \\
& BUS & 27.286 & 34.036 & 48.014 & 79.186 & 116.930 & 145.924 \\
& UUS & 9.252 & 15.529 & 18.076 & 18.333 & 28.536 & 51.064 \\
\hline 5 & Total DPK & 36.852 & 52.271 & 76.036 & 115.415 & 147.512 & 150.795 \\
\hline
\end{tabular}

\section{PASAR BEBAS ASEAN}

\section{Pengertian}

Pasar bebas adalah sebuah konsep ekonomi yang mengacu pada penjualan produk antar negara tanpa pajak ekspor-impor atau hambatan perdagangan lainnya. Perdagangan bebas dapat juga didefinisikan sebagai tidak adanya hambatan buatan (hambatan yang diterapkan pemerintah) dalam perdagangan antar individual-individual dan perusahaan-perusahaan yang berada di negara yang berbeda.

\footnotetext{
${ }^{17}$ compass.com. ekonomi 25/11/2013

18 Sumber data: Statistik Bank Indonesia, Vol.11, No.3 Februari 2013
} 
Perdagangan Internasional sering dibatasi oleh berbagai pajak negara, biaya tambahan yang diterapkan pada barang ekspor impor, dan juga regulasi non tarif pada barang impor. Secara teori, semuha hambatan-hambatan inilah yang ditolak oleh perdagangan bebas. Namun dalam kenyataannya, perjanjian-perjanjian perdagangan yang didukung oleh penganut perdagangan bebas ini justru sebenarnya menciptakan hambatan baru kepada terciptanya pasar bebas. Perjanjian-perjanjian tersebut sering dikritik karena melindungi kepentingan perusahaan-perusahaan besar.

\section{Organisasi Pasar Bebas ASEAN}

1. AFTA

Secara khusus, Kawasan Perdagangan Bebas ASEAN (Bahasa Inggris: ASEAN Free Trade Area atau AFTA) adalah sebuah persetujuan oleh ASEAN mengenai sektor produksi lokal di seluruh negara ASEAN. Proses perintisannya dicanangkan sejak KTT ASEAN di Singapura tahun 1992. Sedangkan realisasinya pada mulanya disepakati berlaku ntahun 2008, tapi kemudian diajukan AFTA disepakati berlaku tahun 2003.

Ketika persetujuan AFTA resmi ditandatangani, ASEAN baru memiliki enam Negara anggota, yaitu, Brunei, Indonesia, Malaysia, Filipina, Singapura dan Thailand. Vietnam bergabung pada 1995, Laos dan Myanmar pada 1997 dan Kamboja pada 1999. AFTA sekarang terdiri dari sepuluh negara ASEAN. Keempat pendatang baru tersebut dibutuhkan untuk menandatangani persetujuan AFTA untuk bergabung ke dalam ASEAN, namun diberi kelonggaran waktu untuk memenuhi kewajiban penurunan tarif AFTA. ${ }^{19}$

Tujuan Pasar Bebas ASEAN

- Meningkatkan daya saing ASEAN sebagai basis produksi dalam pasar dunia melalui penghapusan bea dan halangan non-bea dalam ASEAN

- Menarik investasi asing langsung ke ASEAN

2. ASEAN Economic Community (AEC) / Mayarakat Ekonomi ASEAN (MEA)

Cikal bakal disepakatinya AEC adalah ditandatanganinya ASEAN Charter di Singapura. UUD ASEAN ini diratifikasi oleh setiap parlemen negaranegara ASEAN pada tanggal 11 November 2008. Selanjutnya diberlakukannya ASEAN Charter tersebut pada tanggal 15 Desember 2008. ${ }^{20}$

Kita akan menghadapi ASEAN Economic Community (AEC), atau yang lebih dikenal sebagai Pasar Bebas ASEAN 2015. AEC akan aktif diterapkan pada 1 Januari 2015, dan itu artinya hanya tinggal beberapa bulan lagi. Sayangnya, gaung Pasar Bebas ASEAN 2015 seolah begitu sayup terdengar, padahal kita tidak mudah menghadapi AEC. Pada saat itu, kita akan berkompetisi dengan semua negara di ASEAN, karena mereka bebas masuk di pasar Indonesia, dan itu merupakan persaingan yang berat.

AEC terdiri dari tiga pilar utama yang saling terintegrasi yaitu ASEAN Scurity Community, ASEAN Economic Community, dan ASEAN Socio Culture Community. Tujuan utama AEC adalah untuk mendorong efisiensi dan

\footnotetext{
${ }^{19}$ Bob Widyahartono Dari AFTA menuju Komunitas ekonomi ASEAN.www.unisosdem.org.Diakses tanggal 5 Februari 2014.

${ }^{20}$ Kompasiana.com.mudi 2012.
} 
daya saing ekonomi kawasan ASEAN, seperti yang tercermin dalam blueprint AEC yaitu:

1. Menuju single market and production base (arus perdagangan bebas untuk sector barang, jasa, investasi, pekerja trampil dan modal)

2. Menuju penciptaan kawasan regional ekonomi yang berdaya saing tinggi

3. Menuju kawasan dengan pembangunan ekonomi yang merata melalui pengembangan UKM dan program-program lainnya

4. Menuju integrasi penuh pada ekonomi global

Mungkin pada saat ini, kita tidak terlalu banyak memiliki kompetitor, namun pada 2015, boleh jadi kita akan berkompetisi dengan begitu banyak pihak dari sejumlah negara. Kompetisi itu lebih dari sekedar soal harga, ongkos atau biaya, namun juga menyentuh soal kualitas atau standarisasi. Yah, kita harus bersiap mulai dari saat ini.

Perbedaan utama antara AFTA da AEC adalah kalau AFTA baru upaya pemebebasab beban tarif perdagangan antar negara, sementara AEC/MEA 2003 adalah bentuk kerjasama yang berusaha membebaskan tarif dan non tariff. ${ }^{21}$

\section{Peluang-peluang Lembaga Keuangan Syariah Dalam Pasar Bebas ASEAN}

Indonesia akan menjadi lahan yang subur bagi pertumbuhan ekonomi Islam. Pasalnya, Indonesia memiliki potensi yang besar untuk itu. Beberapa potensi tersebut antara lain, keikutsertaan Indonesia dalam berbagai kelompok negara, seperti G20 dan APEC. Selain itu, Indonesia merupakan negara Muslim terbesar di dunia, Indonesia juga memiliki pengalaman pembangunan yang cukup lama dengan mengadopsi sistem sosialis dan kapitalis dan ini menjadi aset untuk membangun sistem perekonomian Indonesia yang berdasarkan pada agama dan kepribadian budaya.

Selain itu, bangunan konstitusi negara dan ideologi ekonomi Pancasila sudah sejalan dengan ekonomi Islam. Bahkan, perkembangan kelembagaan ekonomi Islam dan perundang-undangan yang di Idnonesia cukup marak dalam 10 tahun terakhir," jelas Islamic Development Bank (IDB) Field Representative for Indonesia, M Makhlani, dalam Stadium General Fakultas Ekonomi Universitas Negeri Yogyakarta (UNY). ${ }^{22}$

MEA 2015 dapat memberikan peluang dan sekaligus tantangan untuk mengembangkan pasar bagi industri keuangan syariah, sehingga industri keuangan syariah bisa beroperasi lintas negara ASEAN. Dalam menghadapi MEA 2015, kami juga menerapkan kebijakan dan regulasi yang mendukung industri keuangan syariah Indonesia," ujar Muchlasin ketika ditemui dalam Dialog Keuangan Syariah di Menara Anugerah, Jakarta, Kamis (19/9/2013). ${ }^{23}$

21 Petikdua.wordpress.com/2009/11/11/Regionalism di kawasan Asia Tenggara.Diakses tanggal 2 Februari b2014.

22 Harian Republika.Co.Id, Yogyakarta, Kamis, 20 September 2012.

${ }^{23} \mathrm{http}$ ///bisnis.liputan6.com/read/697566/5-cara-lembaga-keuangan-syariah-bersaing-diasean-2015 
Prospek Industri keuangan syariah nasional saat ini, sangat baik dan cukup cerah, baik perbankan syariah maupun asuransi syariah maupun yang lain. Asset industri keuangan syariah terus meningkat secara signifikan. Untuk beberapa tahun ke depan diprediksi masih berpeluang besar untuk terus meningkat. Saat ini market share perbankan syariah hampir 4 persen, dan di tahun depan diperkirakan mencapai 5 persen. Prediksi ini didasarkan pada trend pertumbuhan industri keuangan syariah selama ini.

Yang paling penting dicatat, pasar Indonesia, masih terbuka luas. Inilah yang membedakan Indonesia dengan Timur Tengah, Eropa dan Malaysia. Jika Timur Tengah tergantung pada produksi minyak, demikian pula Eropa, Bank-bank Eropa banyak menampung dana dari pengusaha minyak Timur Tengah, sehingga tetap tergantung pada produksi minyak Timur Tengah, Karena itu trend pertumbuhannya belakangan biasa-biasa, saja, berkisar 10 sd 15 persen setahun. Sementara Malaysia perkembangan keuangan syariah banyak didukung pemerintah. Dana yang dikelola lembaga keuangan syariah di negeri jiran ini banyak berasal dari dana pemerintah, Dari asset perbankan syariah yang mencapai Rp 600 triliun, 90 persennya adalah dana pemerintah (BUMN), Jadi hanya 10 persen dana masyarakat sekitar Rp 60 triliun.

Jika dibanding dengan Indonesia, dana pihak ketiga bank syariah di negeri ini, masih jauh lebih banyak daripada dana pihak ketiga bank syariah di Malaysia.

Masih luasnya pasar syariah yang belum digarap, dapat dilihat dari fakta bahwa, ada lebih dari 200 juta Muslim di Indonesia dan kesadaran akan keislamannya terus meningkat. Hal ini merupakan peluang pasar yang lebar bagi industri keuangan syariah. Permintaan terhadap kehadiran lembaga keuangan syariah di berbagai tempat terus meningkat. Sejalan dengajn itu, momentum krisis keuangan global membawa hikmah bagi perkembangan industri syarioah di Indonesia.

Krisis ekonomi akhir-akhir ini memperlihatkan bahwa dunia dan Indonesia memerlukan konsep lain dalam menata perekonomiannya. Lembaga ekonomi syariah adalah pilihan yang paling tepat. Oleh karena itu, untuk memenuhi kebutuhan pasar, di samping juga mendidik masyarakat, diperlukan lebih banyak bank dan asuransi syariah, dan alhamdulillah kini telah banyak bermunculan asuransi syariah sebagai counterpartnya yang jumlahnya malah melebihi jumlah lembaga perbankan syariah. ${ }^{24}$

\section{Tantangan-tantangan LKS dalam Pasar Bebas}

Oleh karena pasar bebas merupakan tuntutan globalisasi, maka kita harus menerimanya dengan persiapan-persiapan ekstra keras. Kita harus proaktif mengantisipasi kemungkinan dampak pasar bebas yang merugikan, terutama bagi pengembangan usaha rakyat kecil.

Secara teori, antisipasi sederhana, yakni meningkatkan daya saing. Peningkatan daya saing ini harus bersumber dari peningkatan efisiensi dan produktivitas (peningkatan nilai tambah), dan tidak bisa melalui cara lain. Proteksi untuk sementara

\footnotetext{
${ }^{24}$ Wawancara Ekslusif dengan Bapak Agustianto, Ketua I IAEI, https://www.google.com/\#q=prospek+dan+tantangan+lembaga+keuangan+syariah+di+indone sia
} 
masih bisa digunakan untuk menopang daya saing di pasar dalam negeri. Itu pun secara bertahap harus dilepaskan. Lebih cepat, lebih baik, karena proteksi membuat beberapa lini ekonomi berproduksi secara efisien. ${ }^{25}$

Peningkatan daya saing untuk memenangkan pertarungan pasar bebas di pasar dunia, dapat diwujudkan dengan beberapa faktor, di antaranya peningkatan kualitas SDM, penguasaan teknologi dan penguatan kelembagaan. Seluruh kebijaksanaan ekonomi, baik makro maupun sektoral, baik moneter, fiskal maupun sektor riel, harus diarahkan dalam kerangka yang demikian.

Pemerintah daerah di era otonomi harus proaktif melakukan terobosan-terobosan konstruktif untuk mengantisipasi pasar bebas, di antaranya dengan penetapan core bisnis dan produk unggulan yang tepat dari suatu daerah. Pemda mestinya proaktif menyelenggarakan pelatihan SDM dan harus bekerja sama dengan perguruan tinggi dalam melaksanakan program itu. Dengan demikian ekonomi rakyat bisa berdaya memasuki pasar bebas. ${ }^{26}$

Menurut Direktur Industri Keuangan Non Bank Syariah OJK, Moch. Muchlasin, sedikitnya ada lima tantangan bagi industri jasa keuangan, yaitu:

1. Produk yang sesuai untuk pasar ASEAN, artinya LKS harus mampu menyediakan produk-produk yang sesuai dengan kebutuhan pasar ASEAN.

2. Tingkat kesehatan perusahaan, LKS harus benar-benar memiliki perusahaan yang sehat, modal cukup, hutang proporsional, dan kinerja lancer.

3. Efisiensi usaha, LKS harus mampu beroperasi secara efisien.

4. Daya saing sumber daya manusia (SDM), LKS harus memiliki SDM yang handal, professional, dan amanah.

5. Menjaga kepentingan bisnis dan kepentingan nasional. LKS harus mampu mengemban tugas untuk menjaga kepentingan bisnis dan kepentingan nasionaol secara harmonis, proporsional, dan bertanggung jawab.

Khusus untuk industri keuangan syariah, harus ada masterplan dalam menghadapi MEA $^{27}$

Berkaitan dengan dinamika gerakan ekonomi Islam sendiri, Sesuai dengan perkembangan ekonomi global dan semakin meningkatnya minat masyarakat terhadap ekonomi dan perbankan Islam, ekonomi Islam menghadapi berbagai permasalahan dan tantangan-tantangan yang besar. Dalam usia yang masih muda tersebut, setidaknya ada lima problem dan tantangan yang dihadapi ekonomi Islam saat ini, yaitu :

pertama, masih minimnya pakar ekonomi Islam berkualitas yang menguasai ilmu-ilmu ekonomi modern dan ilmu-ilmu syariah secara integratif. .

Kedua, ujian atas kredibiltas sistem ekonomi dan keuangannya,

\footnotetext{
25 Jhamtani, Hira. 2005. WTO dan Penjajahan Kembali Dunia Ketiga. Insist Pers.Yogyakarta. Lihat juga Fakih, Mansour. 2003. Bebas dari Neoliberalisme. Insist Pers. Yogyakarta

${ }^{26} \mathrm{http}: / / \mathrm{www}$.agustiantocentre.com/?p=695

${ }^{27}$ Dialog Keuangan Syariah: 'Tantangan Lembaga Keuangan Syariah Menghadapi Pasar Bersama ASEAN 2015' di Jakarta, Kamis, 19 September 2013.
} 
ketiga, perangkat peraturan, hukum dan kebijakan, baik dalam skala nasional maupun internasional masih belum memadai .

Keempat, masih terbatasnya perguruan Tinggi yang mengajarkan ekonomi Islam dan masih minimnya lembaga tranining dan consulting dalam bidang ini, sehingga SDI di bidang ekonomi dan keuangan syariah masih terbatas dan belum memiliki pengetahuan ekonomi syariah yang memadai.

Kelima, peran pemerintah baik eksekutif maupun legislatif, masih rendah terhadap pengembangan ekonomi syariah, karena kurangnya pemahaman dan pengetahuan mereka tentang ilmu ekonomi Islam. ${ }^{28}$

Sementara itu dalam ahli-ahli yang lain, Robert Hormats, seorang Vice Chairman dari sebuah bank investasi multi nasional yang berkantor di pusat New York, secara jujur mengatakan, "volatilitas international telah menjadi sedemikian rupa, sehingga pasar bebas kapitalisme menjadi deskrutif". Pernyataan lain yang serupa dituturkan Anthoni Giddens, Direktur London School of Economics, menurutnya, di era pasar global dan pasar bebas, banyak masyarakat di berbagai negara yang akan tergilas dan tak terlindungi.

Seorang intelektual Perancis yang memiliki pengikut besar, Piere Bourdie, yang bahkan disebut sebagai figur terdekat Jean Paul Sartre berpendapat bahwa tujuan sentral dari logika murni sistem pasar adalah melemahkan setiap kolektif group, apakah itu negara, bangsa, serikat buruh, koperasi, organisasi corporasi-untuk diganti dengan apa yang disebut sebagai kekuasaan mendunia dari fleksibelitas yang mutlak, di mana modal dan perusahaan-perusahaan mendikte term-term dari pekerjaan dan upah. Dengan lugas di menuliskan refleksinya terhadap dunia dewasa ini, "Dunia kita adalah dunia Darwinisme yang selalu tak aman dan senantiasa rawan stress, di mana ancaman permanen akan kehilangan pekerjaan, menciptakan keresahan yang permanen pula".

Di Seatle, AS, jaringan Lembaga Swadaya Masyarakat paling berpengaruh di dunia melakukan demontrasi besar-besaran menggugat globalisasi perdaganganbebas yang dirunding WTO. Menurut mereka, konsep pasar bebas adalah sebuah kezaliman dan jelas-jelas tidak akan membawa keadilan, karena lebih menguntungkan negara maju, terutama AS. Malah globalisasi arus modal telah melahirkan krisis moneter, mulai dari Eropa, Amerika Latin, hingga Asia. Meskipun pemerintah AS tidak mengakui demo tersebut, tapi Presiden Clinton membuat statemen bahwa dirinya merasa simpati terhadap demo tersebut.

Kecenderungan liberalisasi ekonomi di satu pihak ingin menciptakan pertumbuhan ekonomi tinggi, tetapi di lain pihak membawa pula kecenderungan meningkatnya ketimpangan pendapatan. Ketimpangan ini terjadi karena berbedanya kemampuan golongan masyarakat dalam memanfaatkan kesempatan yang diciptakan oleh mekanisme pasar. Bagi golongan ekonomi kuat, liberalisasi ekonomi berarti kesempatan untuk tumbuh dengan cepat, sedangkan bagi ekonomi lemah berbagai hambatan permodalan, sumber daya manusia, keterampilan dan kelembagaan

\footnotetext{
${ }^{28}$ Agustianto, Tantangan Ekonomi Syariah dan Peran Ekonom Muslim, Artikel Islamic Economic, 2013.
} 
(manajemen) tidak memungkinkan mereka mendapatkan kesempatan yang sama. Masalah ini harus diselesaikan sehingga pertumbuhan yang berjalan bersama-sama. Hanya dengan pertumbuhan yang berjalan dengan seiring dengan pemerataan, maka pembangunan nasional dapat sinambung.

Sementara itu Otoritas Jasa Keuangan (OJK) mengingatkan agar Industri Keuangan Non Bank (IKNB) syariah, seperti Asuransi Syariah, Multifinance Syariah, dan lain-lain untuk mempersiapkan diri menghadapi Masyarakat Ekonomi ASEAN (MEA) pada 2015. Pasalnya, jika tidak menganggapnya serius, IKNB syariah nasional akan kalah diserbu pihak asing. Direktur IKNB Syariah OJK Mochammad Muchlasin mengatakan, saat ini 'ancaman' terbesar untuk pasar keuangan syariah nasional yaitu berasal dari Malaysia, Brunei Darussalam, dan Singapura. Pasalnya, ketiga negara tersebut telah memiliki industri keuangan syariah yang telah berkembang pesat.

Penduduk Indonesia ada 250 juta orang, rasanya terlalu menggiurkan kalau tidak dimasuki oleh mereka. Apalagi, mayoritas pasar kita di mikro, jadi ada tantangan bagi industri untuk mempersiapkan diri. ${ }^{29}$

Namun, dia tidak memungkiri, kendati terdapat kemudahan regulasi untuk ekspansi IKNB syariah di Malaysia dan Singapura, contohnya, banyak hal-hal tidak tertulis yang cenderung menyulitkan. Sebab itu, menurut Muchlasin, sangat perlu untuk industri nasional mempersiapkan diri dan menjaga pasarnya di dalam negeri. Tentunya sebisa mungkin kami tidak segampang itu membiarkan mereka (asing) masuk.

Untuk memperkuat IKNB syariah domestik, lanjutnya, OJK telah mengeluarkan aturan bagi Asuransi Syariah untuk meningkatkan modalnya menjadi Rp 50 miliar untuk perusahaan terbatas (PT) full fledge dan Rp 25 miliar untuk unit usaha syariah (UUS) milik asuransi konvensional. OJK juga telah mengeluarkan aturan rasio solvabilitas (risk based capital/RBC) Asuransi Syariah.

Menurut dia, jika perusahaan Asuransi Syariah lokal kuat dan sehat, maka akan lebih siap untuk bersaing dengan pihak asing. Tidak hanya dari sisi perusahaan, OJK mendorong peningkatan kualitas sumber daya manusia (SDM) Asuransi Syariah. Sekarang standar kompetensi asuransi syariah sudah ada, termasuk konvensional. Yang belum ada itu lembaga untuk sertifikasi profesinya. Kami masih membahasnya dengan asosiasi," ujar Muchlasin. ${ }^{30}$

OJK mengungkapkan sejumlah langkah yang disiapkan tersebut adalah pertama, mengembangkan kerangka regulasi yang mendukung pengembangan pasar modal dan IKNB syariah. Kedua, mengembangkan produk pasar modal dan jasa keuangan non bank syariah. Selain dua strategi itu, OJK juga akan mengupayakan kesetaraan produk keuangan syariah dengan produk konvensional, meningkatkan pengembangan sumber daya manusia di pasar modal dan IKNB syariah, serta mendorong peningkatan kualitas tata kelola perusahaan yang baik.

\footnotetext{
${ }^{29}$ Muchlasin, dalam Dialog Tantangan Lembaga Keuangan Syariah Menghadapi Pasar Bersama ASEAN 2015, Jakarta, Kamis (19/8).

${ }^{30}$ ww.beritasatu.com/ekonomi/139355-iknb-syariah-diminta-persiapkan-diri-hadapi-pasar-bebasasean.html
} 
Muchlasin menegaskan, selain program pengembangan masterplan, Otoritas Jasa Keuangan juga akan melakukan beberapa kegiatan dalam menghadapi MEA 2015 seperti memberikan edukasi dan promosi industri keuangan syariah, meningkatkan akses informasi terhadap produk-produk industri keuangan non bank syariah dan mengembangkan kerangka pengawasan dan pembinaan yang mendukung bisnis industri keuangan non bank syariah. ${ }^{31}$

\section{PENUTUP}

Dari beberapa uraian di atas, dapat disimpulkan beberapa hal di bawah ini :

Lembaga Keuangan Islam atau yang lebih popular disebut Lembaga Keuangan Syari'ah adalah suatu lembaga keuangan yang prinsip operasinya berdasarkan pada prinsip-prinsip syari'ah Islamiah. Bentuknya dapat meliputi: Perbankan Syariah, BMT, Asuransi Syariah, Reksadana Syariah, Pasar Modal Syariah, Pasar uang Syariah, Anjak Piutang Syariah, Koperasi Syariah, Lembaga Zakat, Infaq, Shadaqah dan Wakaf, Pegadaian Syariah, Leasing Syariah, Modal Ventura Syariah dan Dana Pensiun Syariah. Dalam operasionalnya lembaga keuangan Islam ini harus menghindari unsur riba, gharar, maisir dan akad-akad yang bathil. Adapun akad-akad utama yang digunakan adalah: Musyarakah, Mudharabah, Wadiah, Ijarah, Rahn, Kafalah, Wakalah, Hiwalah, Bai' dan Qardh.

Pasar bebas ASEAN adalah perdagangan yang dilakukan oleh penduduk di dalam negara-negara anggota ASEAN dengan berbagai kemudahan dan kebebasan hambatan baik tariff maupun non tariff, baik secara regional, bilateral maupun multilateral. Organisasi Pasar bebas ASEAN meliputi AFTA dan AEC. AFTA atau dalam bahasa Inggrisnya ASEAN Free Trade Area, adalah sebuah persetujuan oleh ASEAN mengenai sektor produksi lokal di seluruh negara ASEAN. Sedangkan AEC (ASEAN Economic Community / Mayarakat Ekonomi ASEAN (MEA). Cikal bakal disepakatinya AEC adalah ditandatanganinya ASEAN Charter di Singapura. UUD ASEAN ini diratifikasi oleh setiap parlemen negara-negara ASEAN pada tanggal 11 November 2008. Selanjutnya diberlakukannya ASEAN Charter tersebut pada tanggal 15 Desember 2008

AFTA dan MEA 2015 dapat memberikan peluang dan sekaligus tantangan untuk mengembangkan pasar bagi industri keuangan syariah di Indonesia, karena industri keuangan syariah akan beroperasi dengan lintas negara ASEAN.

Peluang-peluang Lembaga Keuangan Syariah Dalam Pasar Bebas ASEAN antara lain: Indonesia akan menjadi lahan yang subur bagi pertumbuhan ekonomi Islam. Pasalnya, Indonesia memiliki potensi yang besar untuk itu seperti keikutsertaan Indonesia dalam berbagai kelompok negara, semisal G20 dan APEC. Selain itu, Indonesia merupakan negara Muslim terbesar di dunia, Indonesia juga memiliki pengalaman pembangunan yang cukup lama dengan mengadopsi sistem sosialis dan

\footnotetext{
${ }^{31}$ http://bisnis.liputan6.com/read/697566/5-cara-lembaga-keuangan-syariah-bersaing-diasean-2015
} 
kapitalis dan ini menjadi aset untuk membangun sistem perekonomian Indonesia yang berdasarkan pada agama dan kepribadian yang berbudaya.

Masih luasnya pasar syariah yang belum digarap, dapat dilihat dari fakta bahwa, ada lebih dari 200 juta Muslim di Indonesia dan kesadaran akan keislamannya terus meningkat. Hal ini merupakan peluang pasar yang lebar bagi industri keuangan syariah. Permintaan terhadap kehadiran lembaga keuangan syariah di berbagai tempat terus meningkat. Di samping itu, momentum krisis keuangan global membawa hikmah bagi perkembangan industri syariah di Indonesia.

Tantangan-tantangan LKS dalam Pasar Bebas

Oleh karena pasar bebas merupakan tuntutan globalisasi, maka kita harus menerimanya dengan persiapan-persiapan ekstra keras. Kita harus proaktif mengantisipasi kemungkinan dampak pasar bebas yang mungkin merugikan, terutama bagi pengembangan usaha rakyat kecil. Sedikitnya ada lima tantangan bagi industri jasa keuangan, yaitu: Pertama, Produk yang sesuai untuk pasar ASEAN, artinya LKS harus mampu menyediakan produk-produk yang sesuai dengan kebutuhan pasar ASEAN. Kedua,Tingkat kesehatan perusahaan, LKS harus benar-benar memiliki perusahaan yang sehat, modal cukup, hutang proporsional, dan kinerja lancer. Ketiga, Efisiensi usaha, LKS harus mampu beroperasi secara efisien. Keempat, Daya saing sumber daya manusia (SDM), LKS harus memiliki SDM yang handal, professional, dan amanah. Kelima, Menjaga kepentingan bisnis dan kepentingan nasional. LKS harus mampu mengemban tugas untuk menjaga kepentingan bisnis dan kepentingan nasionaol secara harmonis, proporsional, dan bertanggung jawab. Khusus untuk industri keuangan syariah, harus ada masterplan dalam menghadapi MEA tersebut.

Sementara berkaitan dengan dinamika gerakan ekonomi Islam sendiri, setidaknya ada lima problem dan tantangan yang dihadapi oleh gerakan ekonomi Islam saat ini, yaitu : pertama, masih minimnya pakar ekonomi Islam berkualitas yang menguasai ilmu-ilmu ekonomi modern dan ilmu-ilmu syariah secara integratif. Kedua, ujian atas kredibiltas sistem ekonomi dan keuangannya. ketiga, perangkat peraturan, hukum dan kebijakan, baik dalam skala nasional maupun internasional masih belum memadai. Keempat, masih terbatasnya perguruan Tinggi yang mengajarkan ekonomi Islam dan masih minimnya lembaga tranining dan consulting dalam bidang ini, sehingga SDI di bidang ekonomi dan keuangan syariah masih terbatas dan belum memiliki pengetahuan ekonomi syariah yang memadai. Kelima, peran pemerintah baik eksekutif maupun legislatif, masih rendah terhadap pengembangan ekonomi syariah, karena kurangnya pemahaman dan pengetahuan mereka tentang ilmu ekonomi Islam.

Ternyata di tengah beragamnya keuntungan yang bisa kita peroleh, pasar bebas ASEAN 2015 juga secara nyata mengandung berbagai pengaruh negatif di dalamnya. Pengaruh tersebut berdampak pula terhadap kondisi kestabilan perekonomian bangsa. Oleh karenanya kawalan terhadap pasar bebas pun akhirnya diperlukan dalam rangka mengantisipasi pengaruh buruk yang bias timbul bagi bangsa Indonesia. 
Jurnal Keislaman, Vol. 2, No. 2, September 


\section{DAFTAR PUSTAKA}

Abdul Ghafur Anshori, Aspek Hukuk Reksadana Syariah Di Indonesia, Refika Aditama, Bandung, 2008

Andri Soemitro, Bank \& Lembaga Keuangan Syariah, KPM Group, Jakarta, 2009.

Bob Widyahartono Dari AFTA menuju Komunitas ekonomi ASEAN. www.unisosdem.org.Diakses tanggal 5 Februari 2014

Bob Widyahartono, Dari AFTA Mепијu Komunitas Ekonomi ASEAN. www.unisosdem.org.

Dialog Keuangan Syariah: 'Tantangan Lembaga Keuangan Syariah Menghadapi Pasar Bersama ASEAN 2015' di Jakarta, Kamis, 19 September 2013.

Dumairi Nor Dkk. Ekonomi Syariah Versi Salaf, Pustaka Sidogiri, Pasuruan, 2008.

HA.Djazuli dan Yadi Janwari, Lembaga-Lembaga Perekonomian Umat, Sebuah Pengenalan, Raja Grafindo Persada, Jakarta 2002.

Harian Republika.Co.Id, Yogyakarta, Kamis, 20 September 2012.

Harian Republika.Co.Id, Yogyakarta, Kamis, 20 September 2012.

http://anshorudin.blogspot.com/2012/03/lembaga-ekonomi-islam.html.Dikutip tgl. 19 Desember 2013

http://anshorudin.blogspot.com/2012/03/lembaga-ekonomi-islam.html. Dikutip: Ahad 9 Desember 2012

Jhamtani, Hira.WTO dan Penjajahan Kembali Dunia Ketiga Insist Pers.Yogyakarta. 2005.

Kompasiana.com.mudi 2012.

Mansour Fakih. Bebas dari Neoliberalisme. Insist Pers. Yogyakarta. 2003

Muhamad, Prinsip-prinsip Akuntansi dalam Al-Quran, UII Press Yogyakarta, 2000.

Muhammad Nejatullah Ash-Shiddiqy, Economic Though of Abu Yusuf, , Aligarh, In Fikri wa Najjar, vol. 5 No 1, Januari 1964

Muhammad Syafi'I Antonio, Bank Syariah Dari Teori Ke Praktek,(Gema Insani: Jakarta) 2001 
Jurnal Keislaman, Vol. 2, No. 2, September

Muhammad.Manajement Bank Syari'ah. (Yogyakarta: Unit Penerbit dan Percetakan, 2012).

Pusat Pengkajian dan Pengembangan Ekonomin Islam (P3EI) UII Yogyakarta Atas Kerja sama dengan Bank Indonesia. Ekonomi Islam. Jakarta:Raja Grafindo Persada. 2000.

Sasli Rais, Pegadaian Syariah: Konsep dan Sistem Operasional (Suatu Kajian Kontemporer, UI Press, Jakarta, 2005.

Statistik Bank Indonesia, Vol.11, No.3 Februari 2013

Veithzal Rival. Islamic financial Management. Jakarta: Galia Indonesia 2010.

Wirdyaningsih, Bank Dan Asuransi Islam Di Indonesia, Kencana Prenanda Media, Jakarta, 2005,

www.beritasatu.com/ekonomi/139355-iknb-syariah-diminta-persiapkan-diri-hadapipasar-bebas-asean.html 